\title{
The Legal Status of State-Owned Share Companies in Ethiopia
}

\author{
Endaweke Tsegaw \\ College of Law, Dire-Dawa University, Dire-Dawa, Ethiopia \\ Email: live2ewenet@yahoo.com
}

Received 14 December 2015; accepted 26 February 2016; published 1 March 2016

Copyright (C) 2016 by author and Scientific Research Publishing Inc.

This work is licensed under the Creative Commons Attribution International License (CC BY). http://creativecommons.org/licenses/by/4.0/

(c) (†) Open Access

\begin{abstract}
Privatization of public enterprises or state-owned business entities has been greatly acclaimed as one of free market ideas and a sort of democratic rule on equitable distribution of wealth. However, ill-designed modes of privatization, particularly, Article 5 of the Proclamation No.146/1998 transfers the public enterprises to share companies in Ethiopia, goes out of the purpose and creates legal and practical problems on the operation of share companies. The crux of this paper focuses on the formation and operation of state-owned share companies which are evolved by the process of privatization in Ethiopia. It advocates that the new advent of formation of company is out of the Commercial Code of the State and legal jurisprudence ever experienced. Hence, the status of such companies is carefully discussed from the legal point of view. These companies situate in different place than company law perspective, the purpose of privatization sought in these companies and the economic policy which the country follows. To this effect, the legal doctrines of the area, the practice of privatization from Privatization and Public Enterprises Supervising Agency (PPESA) are explored.
\end{abstract}

\section{Keywords}

State-Owned Share Companies, Public Enterprises, Privatization

\section{Evolution and Development of Companies in Ethiopia}

Business in organized form has its beginning in Ethiopia during Emperor Menilik’s reign (Punkhrust, 1961). However, small and few firms were in the hands of foreigners who were residing in the empire. For instance, in 1894 emperor Menelik granted a concession to his Swiss advisor, Ilg, authorizing him to establish a company for the purpose of building a Railway from Djibouti to the White Nile through Harar and Entoto (Pankhurst, 1963). In 1905, the Bank of Abyssinia followed the suit, which was established at Addis Ababa as a branch of 
the National Bank of Egypt, which was in turn an English company (Pankhurst, 1963). In 1909, however, a private share company was established under the name of Agricultural and Commercial Development Company of Ethiopia (W/Meskel, 1942). It was incorporated by proclamation of Emperor Menelik II. This company was notable for two basic reasons (W/Meskel, 1942). First, it was the first of its type to be established in Ethiopia. Second, the principles of the company were incorporated in the Law of Companies of 1933 and later in the Commercial Code of 1960. It was actually the beginning of Ethiopian company law.

Towards the end of and after the reign of Menelik II, some more number of foreign companies authorized to do business in Ethiopia were granted concessions (W/Meskel, 1942). Thus, the Law of Companies of 1933 was promulgated to regulate these companies, but the existence of companies was not entirely conditioned by the law. After 1933, what was little progress could have been soon interrupted by the Italian invasion and occupation of Ethiopia. Though the development was regenerated since 1941, it had not been equated to the proliferation of companies during the Commercial Code of 1960. The number of companies had greatly increased (Bekele, 1966).

According to Ethiopian Investment Authority profile on Private investment in Ethiopia, after the 1974 "social revolution", the country declared socialism as political philosophy. Private sector and particularly foreign investors from that time on wards were viewed as exploiters of the labor power, raw material and financial resources of the country (EIA Review, 1992). Therefore, private owned companies were nationalized to form public enterprises. Generally, investment climate in Ethiopia was completely depressed. Hence, one can hardly think of companies in the first fifteen years of the Derge regime. Nonetheless, in approaching to the end of its regime, because of the international political changes and to cope up with the needs of the people, the Derge realized that the socialist economic policy would not be able to bring development and hence, it declared mixed economic policy (EIA Review, 1992).

The profile also stated that, after the fall of the Derge regime, the then Transitional Government of Ethiopia (TGE) issued a liberalized market-oriented economic policy which was basically aimed at gearing the economy towards revival and sustained growth (EIA Review, 1992). Accordingly, the comprehensive economic reform program was initiated. The new economic policy provided for major and significant liberalization with respect to private owned commercial companies, both local and foreign investors in Ethiopia while limiting the role of the state in the economy. Thus, the number of companies in Ethiopia has been experiencing an increase than any time before. Consistent with free market economy, as one modus operandi of privatization, the conversion of a "Public Enterprise to Share Company form" has been taken by the FDRE Government, the successor of TGE. Therefore, it is depicted in Ethiopian Privatization Agency News, pursuant to Proclamation No.146/1998, 62 large scale Public Enterprises have been converted to "share companies" totally owned by the State in 1999 (EPA News,1999). The legal status of these State-owned share companies viewed from different perspectives is the issue solemnly coiled to this paper.

\section{The Transition from Public Enterprise to Share Company}

The concept of transition of the Public Enterprises to Share Companies in Ethiopia is evolved from Article 5 of the Proclamation No.146/1998. Such a new move was undertaken by the power given to the Ethiopian Privatization Agency (hereafter EPA), recently substituted by Privatization and Public Enterprises Supervising Agency (hereafter PPESA). Accordingly, the article reads:

Conversion of an Enterprise to a Share Company

1. The agency may, where it deems it necessary in the course of preparation for privatization, cause the conversion of an enterprise to a share company.

2. The capital of a share company established pursuant to sub-Article (1) of this Article shall be divided in to shares and shall totally be held as Government shares.

3. The provisions of Article 312 (1) (b) and 315 of the Commercial Code shall not be applicable with regard to a share company formed under this Article or by taking an enterprise as government contribution.

4. Until such time that the agency start transferring shares of a company formed pursuant to sub-Article (1) of this Article to private ownership:

a) authorities given to shareholders under the Commercial Code shall be deemed given to the Supervising Authority;

b) all directors of the company shall be appointed by the Supervising Authority; 
c) the provisions of Article 307(1), 311, 347(1) and 349 of the Commercial Code shall not applicable; provided, however, that other provisions of the commercial code shall mutatis mutandis be applicable.

In the general, the laws ${ }^{1}$ governing privatization and public enterprises form at lest two kinds of share companies. The first kind of Share Company is formed by conversion of the previous public enterprise as stated in the above article, which is totally owned by the state. And the second one is a share company formed by contribution of the government with the participation of private investors, where the government contributes a public enterprise as a means of privatization. Yet, the Public Enterprise Proclamation No.25/1992 under Article 47 (2) empowers the Council of Ministers to establish any enterprise as a business organization under the Commercial Code. The Council may establish another share company, which constitutes one of the basic kinds of business organizations under the Commercial Code.

The first kind of company is the peculiar one, while the second can be formed as usual in accordance of the Commercial Code, for the code does not forbid the government contribution in share company, provided that other requirements are complied (Winship, 1974). The third mention seems identical to the first one; because the subsequent law of privatization and the practice witnessed that the means to establish an enterprise as a business organization only through the conversion of the enterprises to share company.

The issues to be raised here, in comparison with the age-old company law in general and Commercial Code of Ethiopia in particular, without defecting the cherished objectives and methods of privatization employed by the process of privatization in Ethiopia are:

Can share companies be formed by excluding the application of core provisions of the Commercial Code concerning number of founders (Art. 307 and 311), depositing at least one fourth of the par value of the shares (Art. 312 (1) (b)), valuation of contribution in kind (Art. 315) and directors and their duty (Art. 347(1) and 349)? Does the application of other provisions of the same where they are deemed necessary enable to say the companies formed in accordance with the Commercial code of Ethiopia? On the other side, transferring of shares has its own objectives, whether the state-owned share companies meet these objectives, and the impact of them in creating fair economic environment should also be evaluated.

\section{The Basic Requirements and Benefits of Share Company}

\subsection{Basic Requirements for Incorporation}

From their root, share companies are business organizations. Business organization is a situation where two or more persons form a group and together carryout business as group. Moreover, pursuant to Art.216 to 226 the Commercial Code, the framers of the venture should comply with all legal requirements such as publication and registration. Non compliance of these requirements results in lack of the legal existence and personality by the law. Moreover, Commercial Registration and Business Licensing Proclamation No.67/1997 clearly made a provision on Art.5 (1) that provides no person shall engage in any commercial activity unless registered in commercial register. It further prohibits the de facto commercial business organization; the organization deemed exists without legal formalities are fulfilled, to some extent, what the Commercial Code recognizes. In this regard, for instance, the law of England, Company Act of 1985 provides that registration is meant to create a corporation; it does not recognize the corporation already incorporated by the promoter (French et al., 2005). Then, the firm acquires legal personality and existence. In addition, the provisions of the Commercial Code Art. 323 and 324 governing share companies augment the legal requirements of registration and publication with the same effect. They also state the documents necessary for depositing and registration, without which the idea of company ends as paper work.

The Ethiopian Commercial Code provides under Art. 210, business organization is any association arising out of partnership agreement. Hence, there are two essential requirements to form business in organized form; association and partnership agreement.

Association refers to a situation where two or more persons form a group. It is the basic corporate idea, mode of thought, thinking several as a group, as one. It enables to create oneness of many by meeting of mind and accumulation of huge capital, without which contribution of capital or sketch of venture would not be materialized to long last operation. Thus, the formation of share company requires at least five persons according to Art. 307 (1) of the Commercial Code.

\footnotetext{
${ }^{1}$ To mention some, Public Enterprise Proclamation No.25/1992, Privatization of Public Enterprise Proclamation No.146/1998 and Privatization and Public Enterprises Supervising Authority Establishment Proclamation No.412/2004 Privatization are the major.
} 
Partnership agreement defined by the Code under Art. 211 as "a contract made by the association undertaking to cooperate, to bring together contribution for the purpose of doing business activities and of participating in the profits and losses arising out thereof”. It is a starting point for a company. A written company contract is a prima-facie evidence of the group idea. Most of the written materials in the subject merge company contract with the memorandum of associations (Nadew, unpublished). But, my understanding sees them as different aspects; because, the starting point of company is the oral or the written contract between the founders up until the registration of the company. The memorandum of association is the formal requirement to be registered and to disclose the company's intention and the specific information of the company for the public. The actions and liabilities of the founders that are stated under Articles 308, 309 and 310 need some partnership agreement.

The minimum amount of capital fixed in advance and divided in to shares, and the minimum nominal par value of each share are other requirements to be complied by the founders. Accordingly, Art.306 prescribes the minimum capital and the minimum par value of the shares to render business in share company as 50,000 and 10 Birr respectively.

However, share companies formed by privatization are devoid of such fundamental elements. These share companies have been named as "Share Company" since 1999 after the action to this effect had been taken by EPA (EPA News, 1999). However, the publication on newspaper about the formation of the companies by Ministry of Trade and Industry was made later on, after the commencement their venture as share company. For instance, the publication of Dire Dawa Food Complex Share Company and Hamaressa Edible Oil Share Company was made on 2005 (Ethiopian Press Agency, 2005). However, registration of commercial businesses is said to be completed on the date of publication on newspaper about the formation and thereby commencement of the business of the venture becomes actual and legal as per Federal Commercial Registration and Business Licensing Proclamation, Art. 5(1). Eventually, the undertakings would be conferred with legal personality and legal existence. In contrast, these share companies acquired legal personality and legal existence before their publication. This shows that these companies were not incorporated according to legal procedure provided by the Commercial Code and other relevant laws.

In light of association and partnership agreement, since the share companies under study are totally owned by the state, one man-company, as mentioned earlier, the minimum number of members and the company contract sought by Commercial Code are abrogated by the law of privatization of public enterprises. It is needless for the process of privatization to suspend the application of provisions of the Commercial Code concerning association and company contract.

\subsection{The Benefits of Share Company}

The suitable organization called companies limited by share or corporation are primarily aimed to carry on a business for the following benefits; accumulation of capital, duration, membership and Transferable shares. The outstanding feature and key advantage of company are that it enables the businessmen to accumulate huge money for long time. Professor Gower, for example, has illustrated that during WWII a bomb killed all the members of one company but the company survived; not even hydrogen bomb can destroyed it (Gower et al., 1992). Companies are of limitless members who may not know one another. The Commercial Code of Ethiopia states that even the company may not know its members holding bearer shares and companies are established for the great object of easy transfer of shares.

However, the companies under discussion are not meant for the aforementioned purposes. For instance, in relation to capital, they had sufficient capital more than the legal minimum requirements. While the capital of share companies under the Commercial Code is paid up by the contribution of the shareholders, the public enterprises are pre-existing public enterprises and their capital is the value of their assets. They also assumed the name "share company" to allocate the assets of the enterprises in to shares in order to ease the transfer of public property to private. However, this mainly constitute one method of privatization, not incorporation of business firm as share company for the purpose of accumulation of capital.

The public enterprises converted to share companies have not conceived such corporate idea-duration of the entity and its purpose. For one reason, as per sub-Art. (1) of Art.5 of Proc. No.146/1998, the conversion is simply taken as one procedure of privatization in the course of preparation for privatization. So, how can a company be formed for the short time of pre-privatization? In addition, at present, PPESA is transferring these share companies to prospective investors who can submit bids for partial or total acquisition of the companies 
(PPESA News, 2015). What will be the post-privatization life of these companies, if they are totally transferred to one or two bidder(s)? For example, PPESA privatized nine share companies to single bidders and private limited companies (plc), who bought the total shares of each company exclusively (PPESA News, 2015). To mention one, Bahirdar Edible Oil Share Company was sold to Ashraf Agricultural Plc, which was the single offeror and owned by two persons. The other companies are also privatized in the same fashion. This method of transferring obstructs the over whole target of privatization and the reason behind the conversion of public enterprises to share companies. (We will discuss this issue in detail in the next topics). Though, there may be governmental monitoring, the future status of the venture in the form of share company or in the other is mostly under the decision of the private owner(s). Therefore, the above long-lasting benefits of company could be not expected from these share companies. Hence, their status in share company form will be changed to any form of business after the withdrawal of the Government ownership.

This benefit of membership is not available in the companies under question. First, the share companies are totally held by Government (one-man company) which is out of the ambit of the Commercial Code. Both in the provisions concerning business organizations in general and share companies in particular, the Ethiopian law of commerce requires more than one person membership (Art. 211 cum. Art. 307(1) of the Commercial Code of Ethiopia). This may be compromised for the Government policy of privatization and its objective particularly sought by the conversion, for instance, broadening ownership base. But this also is being dissociated by flexible PPESA's measures to transfer the companies to potential investors who can bid for total acquisition. Once again, if the companies totally transferred to one or more persons but less than five, they will rather assume the status of other firms it may be proprietorship or partnership in its different form. As illustrated above in the case of Bahirdar Edible Oil Share Company, non compliance of legal requirements in the construction of share companies is also transferred to the private owners unless the concerned authority rectifies it immediately.

The capital of the "share companies" is fixed and divided in to shares by the Public Enterprises Proclamation No. 25/92. The questions of stock exchange market and the valuation of the capital of the companies (as considered in detail under sub-topics 3.1 and 3.2) attire some adverse effects to the transferability of the shares which is not intended by the privatization scheme.

At this juncture, it can be inferred that the converted "share companies" are lacking the above discussed sin qua non elements and advantages of share company. These elements are not the concerns of some specific legal system that can be suspended for short-term purpose as the proclamation No.146/98 does. The Proclamation suspends application of some provisions of Commercial Code while it permits the application other provisions as it deems necessary. But in practice no room is given to single provision. The above mentioned elements are unalienable business universals of companies.

\subsection{Applicable Law}

The responsible law for these entire problems is Proclamation No.146/1998, Privatization of Public Enterprises Proclamation. The proclamation is generally meant basically not to form share companies. However, in order to ease the privatization process, it borrows a single provision with four sub-articles for its conversion of public enterprises to share companies. Beyond this, the proclamation says nothing about the detail rules of the company. Since the privatization of such enterprise could not be an over-night action, even some years have passed after such share companies had been converted to share companies (EPA News, 1999). The law basically employed for the company governance of these share companies can show us the applicable law. Identifying the applicable law in turn serves as litmus test to the status of these companies.

According to sub-4 of Art 5 of the proclamation, until the time that EPA starts transferring shares of the companies to private ownership; the authority given to shareholders meeting under the Commercial Code are given to the Supervising Authority. To name some; the approval of fundamental changes, proposals to changes and reports affecting the company and election of the board of directors are the major. The PPESA is empowered with these powers. However, it has been exercising these powers on the companies not because the fact that the powers of the shareholders in general meeting under the Commercial Code are given to it. Rather, they are inherent powers of the Authority conferred by Public Enterprises Proclamation No. 251/992. The powers of the Supervising Authority (the present PPESA) are also exhaustively enumerated under the same proclamation Art.11 (1), among these, the appointment and removal of the members of the board is the chief one. However, 
for instance, the members of Board of directors of Dire Dawa food complex s.co. ${ }^{2}$ are appointed as per Proclamation No.25/1992 not as per Proclamation No.146/1998. Hence, according to the interview with Ato Afewerk W/Gebe, the then Administrator of Dire Dawa food Complex s.co, the board of directors consists of: two members elected by and from the general assembly of the workers, the General Manager appointed by the government and four government official appointed by the Supervising Authority. On the other side, the Proclamation No.146/1998, however, provides that all directors of the company shall be appointed by the Supervision Authority, in which they are not practically running in the organization and management of state-owned share companies. In addition, as per Ato Wondafrash Asefa, head of Information and Public Relation Service of PPESA, the Supervising Authority is following a uniform procedure and regulations set out by the Proc. No.25/1992, to manage all the public Enterprises irrespective of their form as share companies or not.

Therefore, what can be inferred from the above facts; the law employed for the administration of the companies is the Public Enterprises Proclamation, No.25/1992. Neither the Commercial Code of 1960 nor the Privatization of Public Enterprises Proclamation No.146/1998 is applicable. This, therefore, indicates that these companies are not share companies but Public Enterprises. Thus, Art-5 of the Proc. No.146/1998 concerning the conversion of a public enterprise to a share company, in general and the wording of sub-Article 4 of the same, which tells about the fact that the authorities given to shareholders under the Commercial Code are given to the supervising authority, in particular, are ineffective. For one reason, it does not independently form share companies that exclusively exist out of the status of public enterprises. Secondly, neither it provides the governing rules of such companies, nor it could fully adheres the principles of the Commercial Code governing share companies and forms the share companies in accordance with those principles. The provision, rather, provides for the conversion of some public enterprises to the structure of share companies. But actually, they are still public enterprises with their capital divided in to shares, for the purpose of privatization.

\subsection{Company Governance}

The rubric company governance has an analogy with modern democratic government. In a parliamentary democracy such as Ethiopia, legislative sovereignty rests with parliament, while administration is left to the executive organ of the government based on the constitution (Gower et al., 1992). Likewise, the company democracy is kept by separation of company's power through different organs: the shareholders, directors, managers and auditors based on the two fold constitution: the memorandum of association and articles of association. The point to be raised here is that whether the administrative organization running in state-owned "share companies" could meet the standard centralized organization required by a share company or its analogous corporate form in any legal system.

\subsubsection{The Company's Constitution}

The two fold constitution adapted by the companies enables them to perform their economic and social functions. The company's constitution is originally a very subject matter for the promoters or founders and subject to the verification of the subscribers in the first meeting.

The preparation of memorandum of association is an important step in the formation of the company. As it is depicted in the Commercial Code Art. 313, it is one of the most important documents required to be filed with the registrar of companies at the time of formation of the company. No company can be registered without memorandum of association and hence it sometimes called a life-giving document. It lays down the company's basic constitution: the name clauses, registered office clause, object clause, liability clause and Capital clause. It also defines the limitations and power of the company, beyond which the company cannot commence its activities; otherwise it constitutes Ultra Vires (Singh, 1989). Memorandum of association defines the relationship of the company with outsiders.

Everything else is regarded as a matter of administration to be dealt with in the second document, Articles of association (Gower et al., 1992). The articles of the company are the regulations or bye-laws which govern the internal management of the company. The articles of association may prescribe such regulations for the company as the subscribers to the memorandum deem expedient. They embody the powers of directors, officers and of

${ }^{2}$ Practical investigation of this paper is conducted on Dire Dawa Food Complex Share Company and the uniformity of legal and practical information operating in all state-owned share companies is acquired from the documents and interviews of the concerned officials of PPESA. 
the shareholders' voting etc, the mode and the form in which the business of the company is to be carried out and the changes in the internal regulations can be made. However, such allotment of issues of the company between the two legal documents is alien to the Ethiopian Code of Commerce. Accordingly, Art.313 (10) and (11) of the Code state that the power of directors, auditors, and other officers of the company are designed to be treated under the memorandum of association. Nor the law does provide enumeration of issues to be governed by the articles of association. Rather, it puts under Art. 314 (1) and (2) in general term that the articles of association governs the operation of the company and the procedure how to frame the article. A more surprising deviation is employed by the companies under study. According to the key informant, Ato Zerasion Tsegaye, the then General Manager of Dire Dawa Food Complex s.co, most of the public enterprises and the so-called "Share Companies", including Dire Dawa Food Complex s.co. are devoid of this constitution and its two fold documents. Thus, the efficiency and effectiveness of the management of such share companies without direction of the company constitution is questionable.

\subsubsection{The Company's Organ}

Companies being artificial persons, administration of the affairs of their business demands use of hands, minds and other personalities of representatives who act on behalf of them. The company's affairs managed by its organs. A company has two primary organs; the shareholders' acting collectively in general meeting and the board of directors and their power may extend to managers and auditors and other officers by delegation.

Shareholders can exercise their power acting collectively in the meeting. In meeting, generally, a simple majority vote suffices, but in some cases, a large majority or other special formalities may be required (Gower et al., 1992). Accordingly, the Ethiopian Code of Commerce made provisions under Art. 390 that meeting of Share Company are broadly divided in to two; general and special meetings. However, the companies under study have directors and managers who are not the owners and beneficial of the dividend. They are rather governmental officials and hired officials which are far-heart concerned about the company. Therefore, they can not the company organs to perform the duty of the company towards the shareholders, creditors, workers and public at large. Rather, they are organs of public enterprises meant for governmental purpose. Again, the qualification of such organs for the appointment is not clearly prescribed by the either of the proclamations which form the offices. The National Bank of Ethiopia, according to the power given to it by Proc. No.86/1994, Licensing and Supervision of Insurance Business Proclamation, has the minimum academic standard, qualification and experience required of principal officers and directors of private insurance companies. It might substantially meet the needs to the standard centralized organization, had the proclamation establishing these share companies incorporated similar provisions likewise.

Once we concluded in the above sub-topic that the applicable law on the state-owned share companies is the Public Enterprise Proclamation Proc. No.25/1992, the companies' organ, the power of decision making in the offices of the companies is left to the same. The power of decision making is entrusted to different organs. As set out by the proclamation Art. 10 cum Art.47, it ranges from the Council of Ministers in the apex to the General Manager and his/her deputy General (if any) in the bottom, through the Supervising Authority and the Board of Management in the middle. Still such chain of company governance is uncommon to share companies of Commercial Code. It follows that, does the Commercial Code permit the formation of such business organization by the government to say boldly "Business organization under Commercial Code" (Ethiopian Presses Agency, 2005) $)^{3}$. The answer is conspicuously negative.

\section{Privatization}

Privatization in Ethiopia does not have a long historical background. The concept of privatization was acclaimed in the country after the previous Government Junta Derge fell down and its successor; the FDRE Government planned to change the economic orientation from socialism to capitalism. The very two characteristics of capitalism are private ownership of property and existence of free market. Therefore, to implement these objectives, it is found necessary to launch privatization program on state-owned enterprises, which are mostly the result of the nationalization.

\footnotetext{
${ }^{3}$ Ethiopian Herald says "Notice is hereby given that the "Dire Dawa Food Complex Share Company" has been found in accordance with the commercial code of Ethiopia and Privatization of Public Enterprises Proclamation No.146/1998, and the same statement is employed for publication the Hamaressa Edible Oil Share Company in the same page of the News Letter, and Public Enterprise Proclamation, Art.47(2)(a) states about the establishment of any enterprise as a business organization under the Commercial Code.
} 
Accordingly, a key instrument, Negarit Gazette was proclaimed in 1994 to establish an agency, Privatization Agency (EPA). This proclamation was amended 1996, and later on in 1998 "Privatization of Public Enterprises Proclamation No. 146/98" was enacted. Hence, the EPA was re-established. As the Proclamation Art. 3 reveals the whole idea of privatization is to make the market sufficient and bring suitable economic development by reducing government involvement in the economy. At present, the Agency is merged with the then Ethiopian Public Enterprise Supervising Authority (PESA) to form the Ethiopian Privatization and Public Enterprise Supervising Authority (PPESA) in 2004 as per Privatization and Public Enterprises Supervising Authority Establishment Proclamation No.412/2004. It is in charge of carrying out the process of transferring public enterprises to the private sector in ordinary and efficient manner.

In the last 20 years of privatization process since 1999, about 365 public enterprises have been transferred to the domestic and foreign investors, which worth a total of 18 billion Ethiopian Birr (around \$1 billion) (PPESA, News, 2015). It has fully privatized 329 of these companies, while engaging six others in joint venture schemes. The remaining 25 companies had been illegally nationalized by the military Derg regime, and were eventually returned to their original owners. Among these 62 are share companies which amount 4,266,606,101 Birr establishment capital and converted to shares, that totally owned by the state. As to the objectives of PPESA, the conversion of enterprises in to share companies in order to sell their shares rather than assets, has a number of advantages. These are: (1) buyers will pay less amount of money when they buy shares rather than indivisible assets; (2) broadening ownership base; (3) allow investors to buy shares as much they able; (4) re-sale of shares in portion or in their entirety is possible. However, as illustrated above, the sell of the state-owned share companies without discriminating them from other public enterprises is dissociating these objectives. If they are divided in to shares to the above stated advantages, the bidding processes of sale taken for partial or total acquisition of these companies could not coincide with the intended objectives on privatization of public enterprises in the form of share companies. Secondly, the transferring of these companies to single investor or to a business organization is also obstructing the above stated advantages of transferring shares than assets of the firms. Therefore, generally the suspension of the core provisions of share companies of the Commercial Code ends in vain, or at least without effect. It also caused huge expenditure for restructuring the institutions without benefit.

In addition, keeping the conversion of public enterprises to share companies is normal; it is worthwhile to consider here the necessity of stock exchange market and the precise valuation of capital of an enterprise in order to transfer of these share companies.

\subsection{Stock Exchange Market}

Some people advocate about the need for "stock exchange market" to facilitate the business transaction at large and redistribution of wealth in the country (EPA Review, 2002). The issue of stock exchange is larger than the issue of Share Company. Stock markets are generally one of the efficient ways of capital movements. The most important function stock markets do is raising capital easier and they allow for capital pulling because they facilitate both entry and exit in business.

However, in Ethiopia most businesses are reluctant to organize themselves in the form of share companies. This is attributed to absence of clear and simple entry to and exit from the venture though the business in the area is growing ever before. To invest in a particular company is a very complicated process. Shareholders by themselves should create the market; they have to look for somebody to buy their shares if they want to exit from that company, since there is no market where they go to float their shares. A more surprising point is that there is no legislation and guidelines to create and regulate stock markets independently in the country.

If the then PPESA, according to the power given by the proclamation, interested in privatization some of its plants in the form of share companies, it has to start look around to see people who can buy shares. Here, the government finding might not be free of departmental bias, corruption and political benefit rather than business interests. However, there is no a single stock exchange market exclusively meant for in Ethiopia, just to float the shares and whosoever is interested will buy from there.

Therefore, it is something that the business has to establish carefully in terms of the markets through which such a stock exchange can be done. In relation to the "share companies" converted from public enterprises, stock markets make the transfer of shares to private ownerships effective and transparent. In addition, it would result in smooth business transaction and development of the whole country. But without which the purpose of conversion will be at stake. 


\subsection{Valuation}

One of pre-privatization activity under the proclamation No. 146/98 and the difficult task in practice is the valuation of public enterprises. Pursuant to Art. 5 and 6 of the Proclamation, after the EPA made the decision as to the conversion of public enterprise to a "share company", the capital of the enterprise should be determined, and then it will be divided into shares. The agency made the valuation of an enterprise in accordance with the guidelines issued by its board of management. Moreover, the floor or the indicative price shall be determined based on the valuation and it shall, once again, be subject to the approval of the board.

The type of valuation that should have been carried out is a going-concern value of a business or its asset. This means, as opposed to a liquidation value of a business or its asset, the value of a commercial enterprise's asset and business should be the value of an active business with future earning power. Therefore, there are two valuations; asset valuation and business valuation. The problem in relation to valuation of the enterprises converted to share company is, whether the valuation includes the business valuation and stock valuation (values of good will, chemical formulas and other intellectual properties and raw materials, finished goods, by products etc.) or only the fixed assets valuation. As the proclamation provides in Art. 6(2) "the agency shall cause the valuation of an enterprise or a unit or asset of an enterprise or government shares prior to privatizing same” For instance, the practice in Dire Dawa Food Complex s.co. showed that the fixed assets of the company were valued by the consultant of EPA and the capital restructured with the total capital 79,571,000 Eth. Birr (Dire Dawa Food Complex s.co., Operational Corporate Plan and Report Review, 2005).

In general, some of the companies may acquire huge debt on their operations while the other may perform large extension of their operation and the good will of their business in the market, as they are the two indispensable business truths. For instance Dire Dawa Food Complex Share Company and Harar Brewery Share Company are expanding their production by investing 59,116,000 Eth. Birr and 98 million Ethiopian Birr respectively (PPESA News, 2007). Such changes in the companies and the market fluctuations outside the company seek the revaluation of the capital of the company up until the privatization of each.

In addition, the fixed assets of the companies have been depreciated time to time. The depreciation of fixed assets was valued by EPA consultants and stated at depreciate replacement cost at October 1, 1999. Accordingly, depreciation has been charged on straight line basis on book value at the following per annum: building by 5 per cent, plant vehicle by 16 per cent first year and 12 per cent thereafter, motor vehicle by 20 per cent, office furniture and equipment by 10 per cent, workshop equipment by 12 per cent and Special equipment and tools by 33.33 per cent.

The questions follows that, does the par value of shares which were fixed some years before include such changes throughout the time before privatization?, for the publication made on the Ethiopian Herald shows the capital (fixed asset) that was valued before eight years ago. Accordingly, the capitals of Dire Dawa Food Complex Share Company and Hamaressa Edible Oil Share company were divided in to 79,571 and 81,490 shares respectively having 1000.00 (one thousand Eth. Birr) par value each (The Ethiopian Herald, 2005) based on the 1999 valuation of the companies by EPA. But, this value of the companies is completely different from their present capital and even from the capital they had in the time of publication of the two share companies in 2005.

Therefore, the above problems of valuation of the capital of the share companies and the divided shares affect negatively the transferability of the shares from the government ownership to private ownership. Thereby, the legal status of state-owned "share companies" is questionable since they lack this noble characteristics of share companies-transfer of shares. It seems for this reason that present privatization is shifted to transfer the companies to prospective investors either by partial or total acquisition of the same, rather than individual transfer of the shares as intended (PPESA News, 2007). This defeats the objectives of converting public enterprise to share company stated above.

\section{Economic Policy}

Lastly, this paper tries to evaluate the status of state-owned share companies from economic policy perspective which the country adheres. Even though there is an ongoing debate about how much government should be involved in economic life, in free market economy, the government control and involvement in the business activities should be limited to the areas where the private sector fails to do either for lack of capital or for fear of risk involved. More precisely in the developing countries that adhere to free market economy like Ethiopia, where economic transaction is not much more complicated and more specially where the country launch the Agricul- 
tural-led-Industrialization Development Strategy (ALID and subsequent Growth and Transformation Plan (GTP) the government should play a supportive role to the private sector. Thus, Government undertakes privatization as a measure to change the role and participation of the state in the economy and encourage the participation of the private sector, and thereby to promote the economic development of the country. Basically the mode, conversion of public enterprises to share companies, was intended to accelerate privatization. However, years have passed without shares being sold to the public at large. The first question is, do the state-owned share companies run in accordance with free market economy? Secondly, in the community where share companies are known as private ventures, naming state-owned share companies without any other identification using the term "share companies" may entail misconception about these firms. Thirdly, the state-owned share companies have government funding and subsidies. For instance, Dire Dawa food complex Share Company is established and expanded continuously with the assistance of foreign governments or equipment suppliers, Government fund and domestic banks loan. Notably; foreign loan of Birr 21 million, of these the Italian Government soft loan amounts 18.07 million, the Ministry of Finance contributes 26.60 million and the domestic Bank's loan 6.05 million (Dire Dawa Food Complex so.co. Profile, 2005). In addition, the present expansion of its venture which amounts 59.116 million from domestic bank loan makes the company very huge in Ethiopia and enables to monopolize the market, which adversely affect the private sector small-scale flour mills, biscuit and pasta producers by crowning out from the market. Moreover, in 1997 technical assistance was required from the plant manufacturer and a contract of supervision of machinery erection and commissioning was signed with the Italian company called-PAVAN MAPIMAPIANTI. S.P.A. (Dire Dawa Food Complex so.co. Profile, 2005). Harar Brewery Share Company has also benefited from such kinds of foreign technology transfer during its expansion projects (PPESA News, 2007). Thus, the private sectors have no such opportunity to compete with the state-owned share companies and other enterprises which have the same business activities.

\section{Conclusions}

Though a free-market and liberalized economy has been launched and it's an attractive and applauding ongoing process in Ethiopia under the coming of FDRE into power, there are some practical and legal inconsistencies in the conversion of public enterprises to share company in privatization process. This may be lastly attributed to either the weakness of the private sector. Had it been strong to buy the public enterprises in their crude asset, the laws of privatization would not have prone to create such problems. The legislature and the concerned institutions should have also foreseen it. In free-market economy, the government role to the businesses areas that can be rendered by private sector should be limited to enacting laws concerning formation, ruling and dissolution of companies and concerning fair-trading, antitrust, environmental protection, taxation etc. Though the present Government of Ethiopia has taken an applauding process of privatization, the process shall be continued without creating these legal inconveniencies by naming public enterprise "share companies" for the mere fact that capital divided to shares is common to both with different purpose.

The legal status of these "share companies", thus, due to the above problems enumerated, proved to be "public enterprises" that their capital is divided into shares in order to ease privatization.

Share companies are business organization. However, the share companies under our study are in short of fundamental elements of company, these are association of persons, partnership agreement, publication and registration before commencement of the venture as a share company and centralized company organs. In relation to the formation of share companies, the minimum limit number of persons required and the memorandum of association and articles of association are also not complied.

The administration and management of these companies are ruled by the public enterprises' Proclamation No.25/1992. According to this proclamation, different hierarchy of government agencies and appointees manages the companies' affairs. Even some government higher officials sit on many boards of directors doing justice neither to the boards nor to their own functions. Therefore, their appointment and functions tend to be superfluous and non-functional. On the contrary, their presence inhabits the management of the enterprises for some times business decisions may contradict with politics.

Lastly, Atr-5 of the Proclamation No.146/1998 by which state-owned share companies established is discriminatory clause between the share companies formed by the private shareholders pursuant to the provisions of Commercial Code and the state-owned share companies. Therefore, uniform law governing share companies is not operating in the country. 
Since the whole problems and inconsistencies of laws regarding share companies discussed in this article are resulted from the poor drafting of the Privatization of Public Enterprises Proclamation, No.146/1998, particularly, Articte-5 of the same. The amendment of this Article will rest all the problems solved. Therefore, the amendment of such Article without losing its objective of privatization intended by the proclamation shall be as follows:

Art-5 (Amended)

Public Enterprise their capitals divided into shares.

1. The agency may where it deems it necessary in the course of preparation for privatization cause the division of the capital of an enterprise into shares.

2. The capital of an enterprise which is divided into shares pursuant to sub-Article (1) of this Article shall totally be held as Government shares.

3. The place and the manner of sale of shares of an enterprise shall be prescribed by law.

4. On the time that the agency transfers shares totally to the public, the persons who held the shares shall establish a valid form of commercial business organization according to the Commercial Code.

After shares are transferred to few persons, at least to the minimum number required for formation of Share Company, including the Government as a shareholder, Share Company can be formed in accordance with the Commercial Code provided that the shareholders agreed to form Share Company. Thus, the rest of shares held by the Government can be issued for the public subscription accordingly. Thus the public enterprises converted to share company. Indeed, the Government shall employ some measures to this effect.

\section{References}

Bekele, S. (1966). Private Commercial Companies under Ethiopian Law. Addis Ababa, H.S.I. University.1.

Dire Dawa Food Complex s.co. ( 2005). Company Background Profile.3,57,73.

Ethiopian Investment Authority (1992). A profile on Private Investment in Ethiopia, Review. 11,12.

Ethiopian Press Agency (2005). The Ethiopian Herald, Addis Ababa December 27, Vol. LxII. No. 092.

Ethiopian Privatization Agency (1999). Privatization News, Vol. 2 No. 1. 3,37

Ethiopian Privatization Agency (2002). Privatization Review, Vol. 5 No. 1.6.

Federal Commercial Registration and Business Licensing Proclamation No.67/1997 (1997). Negarit Gazeta (3rd year No.25). Addis Ababa: Brehan ena Selam Printing Press.

French, D., Mayson, S., \& Ryan, C. (2005). Mayson, French and Ryan on Company Law (21st ed.). UK, Oxford University press. 8.

Gower, L. C. B. et al. (1992). Gower's Principle's of Modern Company Law (5th ed.), London: Sweet and Maxwell. $76,15,13,1$

Nadew, L. (unpublished). Business Organization in Ethiopia (p. 49). Teaching Material, Addis Ababa: Ethiopian Civil Service College.

Pankhurst, R. (1963). The Franco-Ethiopian Rail Way and Its History. Ethiopian Observer, 6, 342-379.

Privatization and Public Enterprises Supervisory Authority (2015). PPESA News; Biannual News Magazine published by Information Public Relation Service, Vol. 1, No. 3, 5, 6, 25, 16. www.ppea.gov.et.net

Privatization of Public Enterprises Proclamation No. 146/1998 (1998). Negarit Gazeta (5th Year No. 26). Addis Ababa: Brehan ena Selam Printing Press.

Public Enterprises Proclamation, proc. No. 25/1992 (1992). Negarit Gazeta (51st Year No. 21). Addis Ababa: Brehan ena Selam Printing Press.

Public Enterprises Supervising Authority Establishment Proclamation No. 412/2004 (2004). Negarit Gazeta (10th Year No. 57). Addis Ababa: Brehan ena Selam Printing Press.

Singh, A. (1989). Company Law (9th ed., p. 7). Delhi: Eastern Book Company.

The Commercial Code of Ethiopia of 1960, No. 166/1960 (1960). Negarit Gazeta (19th Year No. 3). Addis Ababa: Brehan ena Selam Printing Press.

W/meskel, B. M. S. (1942). Zikre Neger (p. 320). Addis Ababa: Brehan ena Selam Printing Press.

Winship, P. (1974). Background Documents of the Ethiopian Commercial Code of 1960 (p. 75). Addis Ababa: Artistic Printers. 